\title{
Maxillary Sinus Cancer Pathologic Distant Metastasis TNM Finding v6
}

National Cancer Institute

\section{Source}

National Cancer Institute. Maxillary Sinus Cancer Pathologic Distant Metastasis TNM

Finding v6. NCI Thesaurus. Code C65020.

A pathologic finding about one or more characteristics of maxillary sinus cancer,

following the rules of the TNM AJCC v6 classification system as they pertain to distant metastases. 